\title{
Program Potensi Desa dan Pendayagunaan Bambu Desa Ngalang Kecamatan Gedangsari Kabupaten Gunungkidul Daerah Istimewa Yogyakarta
}

\author{
Arundita Pelangi Larifka Krisma Putri ${ }^{1}$, Bagus Septianto ${ }^{2}$, Brian Cavin Taede ${ }^{3}$, Chrisensiana Sylvia Kusumastuti ${ }^{4}$, Evadne Richard Jamil ${ }^{5}$, \\ Juan Miguel ${ }^{6}$, Peter. D. Lim ${ }^{7}$, Rafly Radyatama ${ }^{8}$, Viona Christya ${ }^{9}$, Yohana Indah Yasa Ningsih ${ }^{10}$, Dismas Persada Dewangga Pramudita ${ }^{11}$ \\ Universitas Atma Jaya Yogyakarta, Jl. Babarsari No.44, Janti, Caturtunggal, Kecamatan Depok, Kabupaten Sleman, Daerah Istimewa \\ Yogyakarta 55281 \\ Email: dismas.persada@uajy.ac.id
}

\begin{abstract}
Community Service Program that focuses on processing village potential result and developing village potential. This work program is carried out to assist village communities in cultivating and developing the village potential they have. So that the community can be creative in cultivating the potential of the village and can develop the potential of the village for the better. The purpose of this work program is to improve the economy for rural communities so that they know more about how to develop and take advantage of the village's potential. The method used in this work program is to identify problems, study literature and collect data, data processing, evaluation and drawing conclucions. The expected results of this work program are the processing of the village's potential, namely processing bamboo into clothes and developing tourism facilities in $4 G$ tourism (Gunung Gentong, Gendangsari, Gunungkidul).
\end{abstract}

Keywords - Work Program, Village Potential, 4G Tourism, and bamboo.

Abstrak - Program Kuliah Kerja Nyata (KKN) ini merupakan program kerja yang berfokus pada pengolahan hasil potensi desa dan pengembangan potensi desa. Program kerja ini dilakukan untuk membantu masyarakat desa dalam mengolah dan mengembangkan potensi desa yang dimiliki. Sehingga masyarakat bisa berkreasi dalam mengolah potensi desa dan bisa mengembangkan potensi desa menjadi lebih baik. Tujuan dari program kerja ini adalah untuk meningkatkan perekonomian bagi masyarakat desa serta untuk meningkatkan pengetahuan bagi masyarakat desa agar lebih mengetahui bagaimana cara mengembangkan dan memanfaatkan potensi desa yang dimiliki. Metode yang digunakan dalam program kerja ini adalah mengidentifikasi masalah, studi pustaka dan pengumpulan data, pemrosesan data, dan evaluasi dan penarikan kesimpulan. Hasil yang diharapkan dari program kerja ini adalah pengolahan potensi desa yaitu mengolah bambu menjadi pakaian dan pengembangan fasilitas wisata yang ada di Wisata $4 G$ (Gunung Gentong, Gendangsari, Gunungkidul).

Kata Kunci-Program kerja, Potesi desa, Wisata 4G, dan Bambu.

\section{PENDAHULUAN}

Desa Ngalang merupakan salah satu desa di Kecamatan Gedangsari, Kabupaten Gunungkidul, Daerah Istimewa Yogyakarta. Luas Desa Ngalang adalah $14,82 \mathrm{Km}^{2}$, atau setara dengan $21,75 \%$ dari luas kecamatan Gedangsari. Data tahun 2013 Desa Ngalang memiliki penduduk sebanyak 9.368 jiwa.

Penduduk Desa Ngalang berdasarkan mata pencaharian rata-rata sebagai petani atau pekebun yang mencapai 3.316 jiwa. Ketinggian tanah di Desa Ngalang rata-rata $100 \mathrm{~m}$ di atas permukaan laut dengan curah hujan rata-rata 7,8 $\mathrm{mm}$ dan jumlah hari hujan rata-rata 85 hari per tahun. Puncak hujan terjadi pada bulan Desember sampai dengan bulan Februari tiap tahunnya. Melihat pada kondisi yang ada, sektor perkebunan, kehutanan, dan peternakan juga mempunyai potensi untuk dikembangkan. Desa ini juga memiliki hasil panen bambu.

Desa Ngalang adalah salah satu desa wisata yang ada di Gunung Kidul. Wisata alam tersebut meliputi wisata alam berupa goa, pantai, tempat bersejarah, pegunungan dan masih banyak lagi. Dari banyaknya potensi pariwisata tersebut salah satunya adalah wisata Puncak $4 \mathrm{G}$ atau Gunung Gentong Gedangsari Gunungkidul. Destinasi wisata ini menyajikan spot alam dan budaya yang sangat menawan seperti gadean, gunung gentong, ormah tiban, dan sebagainya.

Untuk mengembangkan potensi wisata dan hasil panen berupa bambu. Untuk hasil panen bambu sendiri akan dimanfaatkan menjadi pakaian (baju) menggunakan serat bambu, sedangkan untuk pengembangan potensi wisata Desa Ngalang untuk mengembangkan wisata 4G [1].

\section{METODE PENGABDIAN}

Kegiatan Kuliah Kerja Nyata (KKN) 79 Universitas Atma Jaya Yogyakarta menggunakan model KKN Society 5.0 yaitu kegiatan KKN berlangsung tanpa adanya penerjunan secara langsung di lapangan atau dilakukan secara daring atau online.

\section{A. Waktu Pelaksanaan KKN}

Kegiatan KKN 79 Universitas Atma Jaya Yogyakarta (UAJY) diadakan mulai pada 1 April 2021 hingga 31 Mei 2021. Semua bentuk kegiatan KKN ini dilaksanakan secara daring menggunakan bantuan media sosial yaitu Whatsapp dan Microsoft Teams.

\section{B. Materi Penulisan}

Pada kegiatan KKN 79, kelompok 74 terbagi menjadi 2 kelompok kecil untuk mengerjakan program kerja yaitu kelompok potensi desa dan kelompok buku saku. Setiap kelompok mengerjakan $e$-book dan video. Kelompok potensi desa mengambil materi mengenai pemerintahan Desa Ngalang, sejarah Desa Ngalang, fasilitas umum, Sumber Daya Alam (SDA) Desa Ngalang dan objek wisata 4G (Gunung Gentong, Gedangsari, Gunungkidul). Kelompok buku saku mengambil topik pengolahan bambu.

\section{Sasaran Penulisan}

Sasaran penulisan pada kegiatan KKN 79 ini adalah masyarakat di Desa Ngalang, Kecamatan Gedangsari, Kabupaten Gunungkidul, Daerah Istimewa Yogyakarta (DIY) yang merupakan lokasi dari kegiatan pengabdian KKN dilaksanakan secara daring. 
Program Potensi Desa dan Pendayagunaan Bambu Desa Ngalang Kecamatan Gedangsari Kabupaten Gunungkidul Daerah Istimewa Yogyakarta

\section{Sumber Data}

Sumber data yang diambil dalam kegiatan ini adalah melalui website resmi Desa Ngalang untuk mendapatkan informasi-informasi mengenai desa tersebut. Selain itu, pada dasar teori menggunakan sumber data tambahan seperti jurnal, buku, artikel dan website dari internet [2].

\section{E. Tahapan Metodologi}

Langkah pertama tahapan metodologi adalah mengindentifikasi masalah dengan cara mengobservasi atau meneliti permasalahan yang terdapat di Desa Ngalang dan mendapatkan bahwa objek wisata $4 \mathrm{G}$ dan hasil panen bambu dapat lebih dikembangkan atau dioptimalkan.

Langkah kedua adalah studi pustaka dan pengumpulan data yang dilakukan dengan mengambil referensi secara daring melalui berbagai sumber.

Langkah ketiga adalah pemrosesan data yaitu mengolah kumpulan data menjadi sebuah informasi yang kemudian disajikan, baik mengenai identitas Desa Ngalang maupun potensi desa tersebut.

Langkah keempat adalah pemrosesan output yaitu berdasarkan data yang telah dikumpulkan dan disaring melalui pemrosesan data, kemudian dibuatlah output/keluaran berupa laporan, $e$-book, buku saku, dan video sesuai dengan topik permasalahan yang telah ditentukan di awal, yaitu mengenai potensi desa dan pembuatan buku saku. Dari 2 topik tersebut, kelompok KKN 74 dibagi menjadi 2 kelompok kecil. Kelompok 1 mengerjakan potensi desa yang berkaitan dengan pengoptimalan wisata 4G Desa Ngalang. Kelompok 2 mengerjakan buku saku yang berkaitan dengan pembuatan serat bambu menjadi pakaian. Sedangkan untuk pengerjaan laporan kelompok, dikerjakan secara bersamasama.

Langkah kelima adalah melakukan evaluasi dengan mempertimbangkan hal-hal yang sudah dirancang atau dikerjakan apakah cocok dengan objek penelitian. Fungsi dari evaluasi antara lain sebagai umpan balik dalam melakukan perbaikan pada hasil output yang sudah ada, menentukan tingkat keefektifan dari hasil output, dan untuk mengukur tingkat keberhasilan dari hasil yang didapatkan.

Langkah terakhir adalah penarikan kesimpulan berdasarkan hasil evaluasi yang didapatkan.

\section{F. Software yang Digunakan}

Pembuatan pengerjaan laporan dan makalah ini, penulis menggunakan berbagai software yang dapat mempermudah pembuatan. Terdapat 4 software yang digunakan yaitu Canva, Mendeley, Turnitin dan Microsoft Word.

\section{HASIL DAN PEMBAHASAN}

\subsection{Hasil}

Berikut merupakan hasil dan pembahasan dari potensi desa dan pendayungan bambu "Si rumput raksasa":

\subsubsection{Potensi Desa}

\section{A. Wisata di Desa Ngalang}

Desa Ngalang merupakan salah satu desa yang berada di Kecamatan Gedangsari Kabupaten Gunungkidul. Objek wisata puncak Gunung Gentong Gedangsari Gunungkidul (4G) merupakan salah satu potensi wsata yang ada di Desa Ngalang. Gunung Gentong atau yang lebih sering dikenal 4G merupakan sebuah wisata dengan panorama di atas ketinggian dengan lengkap perbukitan yang sangat indah dan juga bisa melihat matahari terbit ataupun matahari terbenam. Walaupun begitu, kami menemukan beberapa masalah atau hal yang perlu diperbaiki dari tempat ini terlebih pada masa pandemi seperti ini [3].

\section{B. Masalah pada Objek Wisata 4G Desa Ngalang}

Beberapa masalah yang kami temukan pada aspek kebersihan, kenyamanan, dan publikasi. Dari segi kebersihan, kondisi pandemi mengharuskan kita sering mencuci tangan sebagai salah satu tindakan preventif terhadap penyebaran virus COVID-19. Berdasarkan observasi kami, jumlah tempat cuci tangan yang tersedia di tempat wisata $4 \mathrm{G}$ Desa Ngalang ini terbilang masih sangat terbatas. Di samping itu, kami juga menemukan bahwa cukup sulit untuk mencari tempat untuk membuang sampah, hal ini tentu menyulitkan para wisatawan yang ingin membuang sampah dan akhirnya mereka cenderung membuang sampah sembarangan yang menyebabkan tempat wisata tersebut menjadi kotor karena sampah-sampah pengunjung berserakan. Masalah selanjutnya adalah dari segi kenyamanan, wisatawan yang datang menurut pengamatan kami pasti merasa kurang nyaman akibat dari kurangnya toilet atau kamar mandi yang tersedia mengingat bahwa toilet merupakan salah satu fasilitas vital di tempat wisata. Aspek terakhir adalah dari segi publikasi. Meskipun telah mempunyai website sendiri, tetapi data yang disajikan masih relatif sedikit dan kurang menarik minat pengunjung [4].

\section{Solusi masalah pada objek wisata 4G Desa Ngalang}

Setelah melihat masalah-masalah yang ada pada objek wisata 4G Desa Ngalang, kami merencanakan beberapa solusi terkait masalah-masalah yang ada. Untuk mengatasi masalah dari aspek kebersihan, tempat cuci tangan harus ditambah jumlahnya serta ditempatkan tidak terlalu berjauhan. Hal ini menjadi sangat penting terlebih pada masa pandemi yang mengharuskan pengunjung agar sering mencuci tangan sebagai tindakan preventif penyebaran virus COVID-19. Tempat cuci tangan yang ada juga harus bisa menyediakan air bersih dan sabun cuci tangan yang cukup untuk pengunjung objek wisata 4G Desa Ngalang. Masalah kebersihan selanjutnya adalah sampah yang dibuang di sembarang tempat. Menambah jumlah tempat sampah dan menempatkannya di berbagai tempat menurut kami adalah tindakan yang tepat guna mengatasi masalah ini. Dari segi kenyamanan, perbaikan fasilitas toilet juga sangat penting karena jumlah yang tersedia saat ini juga masih sangat terbatas. Toilet juga harus selalu bersih agar penggunanya merasa nyaman.

Ketiga solusi di atas tidak hanya mengatasi masalah secara spesifik, tapi juga mengatasi masalah kebersihan lokasi wisata secara umum. Dengan tersedianya tempat cuci tangan, tempat sampah, serta toilet, tentu akan mengurangi peluang berbagai fasilitas wisata lainnya menjadi kotor. Untuk aspek terakhir 
Program Potensi Desa dan Pendayagunaan Bambu Desa Ngalang Kecamatan Gedangsari Kabupaten Gunungkidul Daerah Istimewa Yogyakarta

yaitu publikasi, seharusnya promosi lokasi wisata ini lebih fokus ke arah digital mengingat bahwa dengan teknologi modern saat ini, sangat mudah untuk menyebarkan informasiinformasi melalui sosial media. Promosi juga harus dilakukan secara rutin sehingga lebih dapat menarik minat para wisatawan.

\subsubsection{Pendayagunaan Bambu "Si Rumput Raksasa"}

\section{A. Latar Belakang}

Jenis pekerjaan penduduk di Desa Ngalang cukup beragam. Namun, penduduk di Desa Ngalang lebih banyak bekerja sebagai petani / pekebun. Hasil pertanian unggulan yang dihasilkan oleh Desa Ngalang adalah padi dan palawija. Sedangkan komoditas unggulan yang ada di wilayah Desa Ngalang adalah singkong dan pisang. Desa Ngalang juga merupakan desa yang kaya akan sumber daya alam, sumber daya alam yang dimiliki berupa kayu dan bambu. Masyarakat Desa Ngalang memiliki potensi kerajinan dengan mengembangkan home industry pengolahan kayu. Jenis home industry yang akan dikembangkan yaitu kerajinan patung (loro blonyo, hewan dan lain-lain), kerajinan handicraft dari bahan organik bekas, furniture atau mebel, dan kerajinan bambu [5].

Desa Ngalang juga merupakan desa penghasil sumber daya alam berupa bambu, maka kami memilih untuk membuat buku saku / buku ajar dengan tema kerajinan bambu (membuat baju dari bambu). Jenis bambu yang digunakan adalah jenis bambu tali atau bambu apus. Lalu, bagian bambu yang digunakan adalah batang bambu yang dipotong-potong kemudian diolah menjadi serabut, lalu serabut direndam dengan enzim khusus dan menjadi serat.

\section{B. Manfaat dan Keunggulan}

Bambu mempunyai banyak manfaat dibandingkan dengan bahan utama pakaian lainnya yaitu bambu dikenal sebagai bahan yang lebih environmental friendly dibandingkan dengan bahan lainnya seperti katun, polyester, rayon dan lain sebagainya [6]. Usia dari bambu relative lebih cepat apabila ditanam secara industrial, sekitar 7-8 tahun sudah bisa dipanen untuk dijadikan bahan baku baik itu industrial atau untuk pakaian, bambu secara alami memiliki zat anti-bakteri yang disebut penny quinine yang bisa membuat pakaian anti-bakteri dan bau, memiliki struktur pori-pori kecil khusus di bagian serat bambu memiliki daya serap tinggi, yang mampu menyerap zat formaldehyde, toluene, ammonia, dan beberapa substansi berbahaya lainnya dan kain yang dihasilkan dari bahan bambu bersifat awet, halus, lembut dan dingin pada saat dikenakan [7].

Bambu juga mempunyai beberapa keuntungan dibandingkan dengan bahan utama pakaian lainnya yaitu memiliki zat anti-bakterial alami, kemampuan untuk menyerap dan menghilangkan bau tidak enak, adanya kemampuan permeabilitas terhadap uap air dan dapat menghalangi jumlah sinar ultra-violet yang merusak kulit [8].

\section{Bahan dan Langkah-Langkah Pengolahan}

Bahan yang diperlukan dalam pengolahan bambu menjadi bahan utama pakaian adalah bambu tali, autoclave, natrium hidroksida, hidrogen perkosida 50\%, surfaktan non-ionic, enzim xilanase, mesin softening, pemintal benang, alat tenun dan alat jahit. Terdapat 4 langkah pengolahan bambu menjadi bahan utama yaitu tahap persiapan, proses degumming, proses pengelantangan, dan pemisahan serat bambu.

Tahap persiapan, bambu dipotong sesuai dengan ruas atau bukunya. Kemudian buang bagian bambu yang tidak digunakan, sedangkan bagian bamboo yang digunakan selanjutnya di proses dengan membuang bagian kulit dan dibelah tipis memanjang (Tebalan 0,5-1,0 mm, dan lebar 1-2 $\mathrm{cm})$. Setelah itu persiapkan larutan $\mathrm{NaOH}$ sebanyak $10 \%$ untuk digunakan pada proses selanjutnya (Degumming).

Langkah pertama proses degumming adalah masukan larutan $\mathrm{NaOh} 10 \%$ yang telah dipersiapkan dengan komposisi antara 400-800 ml dan $10 \mathrm{ml}$ surfaktan non-ionic (Rucogen FWK 50) ke dalam autoclave. Setelah itu, masukan air ke dalam autoclave hingga larutan bervolume 4L. Selanjutnya atur autoclave dengan temperatur $900^{\circ} \mathrm{C}$ dan tekanan antara 0,9-1,0 kg/cm2, kemudian masukan bambu yang telah dibelah kedalam autoclave selama 60 menit atau 1 jam. Cuci bambu sebanyak 3-4 kali menggunakan air hingga air bekas cucian terlihat bening.

Proses pengelantangan (bleaching) menggunakan mesin autoclave yang diatur dengan temperatur $900^{\circ} \mathrm{C}$ dengan masukan larutan $\mathrm{H}_{2} \mathrm{O}_{2} 50 \%$ sebanyak $80 \mathrm{~mL}$ ditambah air dengan volume akhir mencapai $4 \mathrm{~L}$. Proses sebelumnya kembali dimasukan ke dalam autoclave tersebut dan diaduk selama 60 menit [9].

Proses pemisahan serat bambu merupakan proses terakhir yang dilakukan. Pada proses ini, bambu hasil bleaching kembali di proses menggunakan mesin softening dan opener. Kemudian serat bambu didapatkan dan siap digunakan. Setelah didapatkan bahan utamanya (serat bambu tali), kemudian dilanjutkan ke proses pembuatan baju. Berikut merupakan langkah-langkah pembuatan baju dari serat bambu tali:

1. Serat bambu tali yang telah halus kemudian dipintal menggunakan mesin pemintal hingga membentuk benang.

2. Kemudian benang hasil pemintalan, di tenun hingga membentuk kain. Kain inilah yang digunakan untuk membuat pakaian.

3. Bentuklah pola pada kain sesuai dengan model dan ukuran yang diinginkan, kemudian potong kain tersebut sesuai pola yang telah dibuat.

4. Jahit kain yang telah dipotong menggunakan mesin jahit.

5. Pakaian dari serat bambu telah selesai [10]. 
Program Potensi Desa dan Pendayagunaan Bambu Desa Ngalang Kecamatan Gedangsari Kabupaten Gunungkidul Daerah Istimewa Yogyakarta

\section{IV.KESIMPULAN}

Kesimpulan yang dapat diambil adalah Desa Ngalang memiliki potensi yang sangat besar untuk dapat lebih berkembang dalam sektor pariwisata dan ekonominya. Namun demikian, kurangnya Infrastruktur dan Sumber Daya Manusia (SDM) yang memadai dalam hal tenaga dan kreativitas menyebabkan pengembangan potensi desa masih belum maksimal. Oleh sebab itu, dengan adanya kegiatan KKN Society 5.0 ini diharapkan para mahasiswa/i dapat memberikan tenaga dan ide terhadap permasalahan yang ada di Desa Ngalang tersebut secara online/daring.

Menanggapi hal tersebut, kelompok KKN 74 membuat rancangan ide untuk meningkatkan potensi Desa Ngalang dari segi pariwisata dan ekonominya. Ide tersebut antara lain meningkatkan potensi Wisata 4G Desa Ngalang dan mengoptimalkan hasil panen Desa Ngalang berupa bambu. Dengan diterapkannya ide tersebut diharapkan Desa Ngalang dapat lebih berkembang. Diharapkannya, dengan perkembangan yang terjadi di Desa Ngalang akan mempengaruhi perekonomian dan pembangunan infrastruktur masyarakat Desa Ngalang.

\section{UCAPAN TERIMAKASIH}

Mengucapkan terima kasih kepada LPPM Universitas Atma Jaya Yogyakarta yang telah ikut serta membantu dalam terealisasikan program Kuliah Kerja Nyata Periode 79 ini.

\section{DAFTAR PUSTAKA}

K. Melalui, K. Kerja, N. Universitas, and A. Dahlan, "PEMBERDAYAAN MASYARAKAT DESA NGALANG, GEDANGSARI, GUNUNG KIDUL MELALUI KULIAH KERJA NYATA UNIVERSITAS AHMAD DAHLAN Sulistyawati dan Suprapti Rejeki," vol. 2, no. 1, pp. 89-94, 2018.

[2] "Website Desa Ngalang," Pemerintah Kelurahan. https://www.ngalang-gedangsari.desa.id/first.

[3] "Rute Dan Lokasi Puncak 4G Gunung Gentong Gedangsari Gunungkidul," datawisata.com. https://www.datawisata.com/gunung-gentong-gunungkidul.

[4] M. N. Attamimi, "Tak Diurus, Wisata Puncak 4G di Gedangsari Gunungkidul Terbengkalai," Jogjapolitan, 2020. https://jogjapolitan.harianjogja.com/read/2020/02/17/513/103207 2/tak-diurus-wisata-puncak-4g-di-gedangsari-gunungkidulterbengkalai.

[5] "Potensi Kerajinan di Desa Ngalang," Kalurahan Ngalang, 2016. https://www.ngalang-gedangsari.desa.id/first/artikel/92-PotensiKerajinan-di-Desa-Ngalang.

[6] B. Andalan, "Pakaian Sehat dari Serat Bambu," Viva.co.id, 2012. https://www.viva.co.id/arsip/281566-pakaian-sehat-dari-seratbambu.

[7] R. A. Adriyana, "Serat Bambu untuk Pakaian, Amankah terhadap Lingkungan? Ini Penjelasannya," 18news.id, 2021 https://18news.id/gaya-hidup/fesyen/serat-bambu-untuk-pakaian-amankah-terhadap-lingkungan--ini-penjelasannya.

[8] S. E. Y. Suprihatin, "Produksi busana," 2010

[9] Mpinoh, "Pembuatan Serat Bambu Sebagai Bahan Tekstil," Luminatiam,

2018 http://luminatiam.blogspot.com/2015/04/pembuatan-seratbambu-sebagai-bahan.html.

[10] T. Wahyudi, C. Kasipah, and D. Sugiyana, "Ekstraksi Serat Bambu Dari Bambu Tali (Gigantochloa Apus) Untuk Bahan Baku Industri Kreatif," Arena Tekst., vol. 30, no. 2, pp. 95-102, 2015, doi: 10.31266/at.v30i2.1958.

\section{PENULIS}

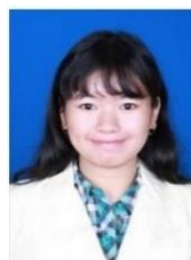

Arundita Pelangi Larifka Krisma Putri, prodi Akuntansi, Fakultas Bisnis dan Ekonomika, Universitas Atma Jaya Yogyakarta.

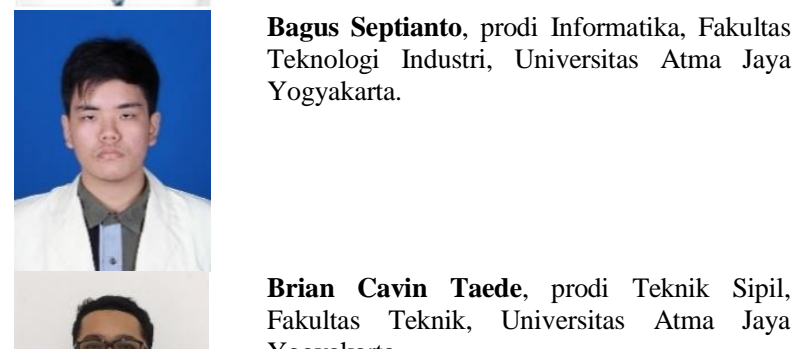

Yogyakarta.

Chrisensiana Sylvia Kusumastuti, prodi Teknik Industri, Fakultas Teknologi Industri, Universitas Atma Jaya Yogyakarta.

Evadne Richard Jamil, prodi Ilmu Komunikasi, Fakultas Ilmu Sosial dan Ilmu Politik, Universitas Atma Jaya Yogyakarta.

Juan Miguel, prodi Informatika, Fakultas Teknologi Industri, Universitas Atma Jaya Yogyakarta.

Peter. D. Lim, prodi Teknik Sipil, Fakultas Teknik, Universitas Atma Jaya Yogyakarta.

Rafly Radyatama, prodi Teknik Sipil Internasional, Fakultas Teknik, Universitas Atma Jaya Yogyakarta. 
Program Potensi Desa dan Pendayagunaan Bambu Desa Ngalang Kecamatan Gedangsari Kabupaten Gunungkidul Daerah Istimewa Yogyakarta

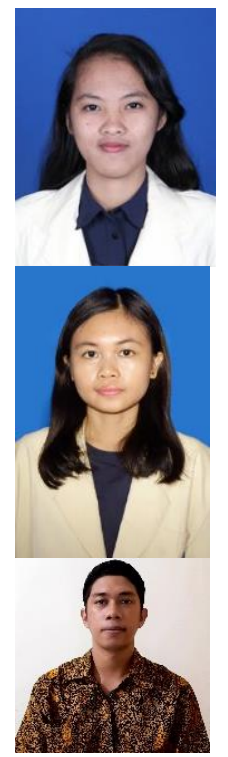

Viona Christya, prodi Ilmu Hukum, Fakultas

Hukum, Universitas Atma Jaya Yogyakarta.

Yohana Indah Yasa Ningsih, prodi Sosiologi, Fakultas Ilmu Sosial dan Ilmu Politik, Universitas Atma Jaya Yogyakarta.

Dismas Persada Dewangga Pramudita, prodi Manajemen, Fakultas Bisnis dan Ekonomika, Universitas Atma Jaya Yogyakarta. 